\title{
Classical and molecular cytogenetic analysis in head and neck squamous cell carcinomas
}

\author{
Luciana CS Veiga ${ }^{1}$, Nádia A Bérgamo ${ }^{1}$, Luiz Paulo Kowalski ${ }^{2}$, Silvia R Rogatto \\ ${ }^{1}$ Departamento de Genética, Instituto de Biociências, UNESP, Botucatu, SP, Brazil. \\ ${ }^{2}$ Departamento de Cirurgia de Cabeça e Pescoço, Hospital A.C. Camargo, São Paulo, SP, Brazil.
}

\begin{abstract}
Head and neck carcinomas represent the sixth most frequent type of cancer in the world, and $90 \%$ are derived from squamous cells (HNSCC). In this study of $15 \mathrm{HNSCC}$ cases, extensive aneuploidy was detected by G banding in most tumors. The most frequently observed numerical changes involved gain of a chromosome 22, and loss of chromosomes $\mathrm{Y}, 10,17$, and 19. The most frequent structural alteration was del(22)(q13.1). As compared to G-banding, fluorescence in situ hybridization (FISH) proved to be an effective technique for detecting aneuploidy. Interphase FISH with a chromosome 17 centromere probe disclosed a high frequency of monosomy for chromosome 17, in contrast with G-banding, by which clonal monosomy 17 was detected in only three of the tumors. Painting probes for chromosomes 5 and 16 were used to evaluate a selected series of HNSCC in which G-banding analysis had shown marker chromosomes. FISH analysis failed to confirm the origin of the marker chromosomes, but four out of five cases showed a significant loss of chromosomes 5 . This difference between FISH and G-banding results may reflect the smaller number of metaphase analyzed as well as the criteria adopted for sorting these metaphases. Therefore results obtained solely by G-banding analysis should be considered with caution. Our data confirmed the involvement of chromosome 17 in head and neck squamous cell carcinomas.
\end{abstract}

Key words: FISH, chromosomal aberrations, head and neck cancer, chromosome 17.

Received: November 22, 2002; accepted: March 28, 2003.

\section{Introduction}

Head and neck carcinomas represent the sixth most frequent cancer in the world, with $90 \%$ of them being derived from squamous cells (Bockmühl et al., 1998). The overall 5-year-survival rate for patients diagnosed with head and neck cancer is estimated at $50 \%$, and this percentage has not changed significantly over the past two decades (Reid et al., 2000). Tropical South America has one of the world's highest age-standardized rates of head and neck cancer (Foulkes et al., 1995). The consumption of tobacco and alcohol appear as the most important non-genetic risk factor associated with the development of head and neck squamous cell carcinomas (HNSCC) (Decker and Goldstein, 1982).

HNSCC develop through the stepwise accumulation of multiple somatic mutations (Nawroz et al., 1994; Califano et al.,1996, 2000). In agreement with this notion, a substantial proportion (40\%) of the reported tumors show intratumoral heterogeneity in the form of cytogenetically related clones (Jin et al., 2002), reflecting the ongoing

Send correspondence to Silvia Regina Rogatto. Depto de Genética, IB, UNESP, 18618-000 Botucatu, SP, Brazil. E-mail: rogatto@ibb.unesp.br. clonal evolution, through which new cell populations with an increased selective advantage emerge (Nowell, 1976).

Cytogenetic studies of HNSCC have revealed a complex pattern of non-random chromosomal abnormalities, and abnormal karyotypes were reported in more than 200 cultured HNSCC. The most frequent losses involved chromosomes 3p, 5q, 7q, 8p, 9p, 11q, 13p, 14p, 15p, and 18q, whereas chromosomal gains usually involved chromosomes 1q, 3q, 8q, and 15q, and band 11q13 (Mitelman et al., 2003). Among the recurrent structural abnormalities, the most common were $8 \mathrm{q}$ isochromosomes, $3 \mathrm{p}$ deletions, and homogeneously stained regions at 11q13 (Jin et al., 1990, 1993, 1995, 1997, 1998, 2002; Rao et al., 1994; van Dyke et al., 1994; Mertens et al., 1997). Losses involving $17 \mathrm{p}$ and gains at $17 \mathrm{q}$ have been frequently reported in HNSCC (Mitelman et al., 2003).

We performed cytogenetic analysis by G-banding in 15 HNSCC cases. Fluorescence in situ hybridization (FISH) with a centromere-specific probe for chromosome 17 was used on interphase nuclei to screen these tumors for aneuploidy. We also used painting probes for chromosomes 5 and 16 to evaluate some tumors, most of them having had marker chromosomes detected by the GTG-banding analysis. 


\section{Material and Methods}

Patients

Fifteen samples of primary head and neck squamous cell carcinomas (HNSCCs) were surgically removed at the Hospital A.C. Camargo, in São Paulo (Table 1). Informed consent was obtained from all patients prior to sampling. This work was performed with the authorization of the Brazilian Federal Ethics Committee-CONEP 813/2000. The medical records of all patients were examined to obtain clinical and histopathological data. For the family history of cancer, first- and second-degree relatives with cancer were considered as positive, and, whenever possible, the evidence of cancer was based on medical records. None of the patients had undergone radiotherapy or chemotherapy before surgery. Histopathological classification was based on the WHO International Classification of Diseases for Oncology (1990). The clinical staging was determined using the TNM Staging System (AJCC, 1998).

\section{Cytogenetic studies}

Fresh tumor samples were obtained under sterile conditions and immediately processed. Chromosome prepara-

Table 1- Features of HNSCC cases: age, sex, histopathological diagnosis, TNM status, clinical data and composite karyotype.

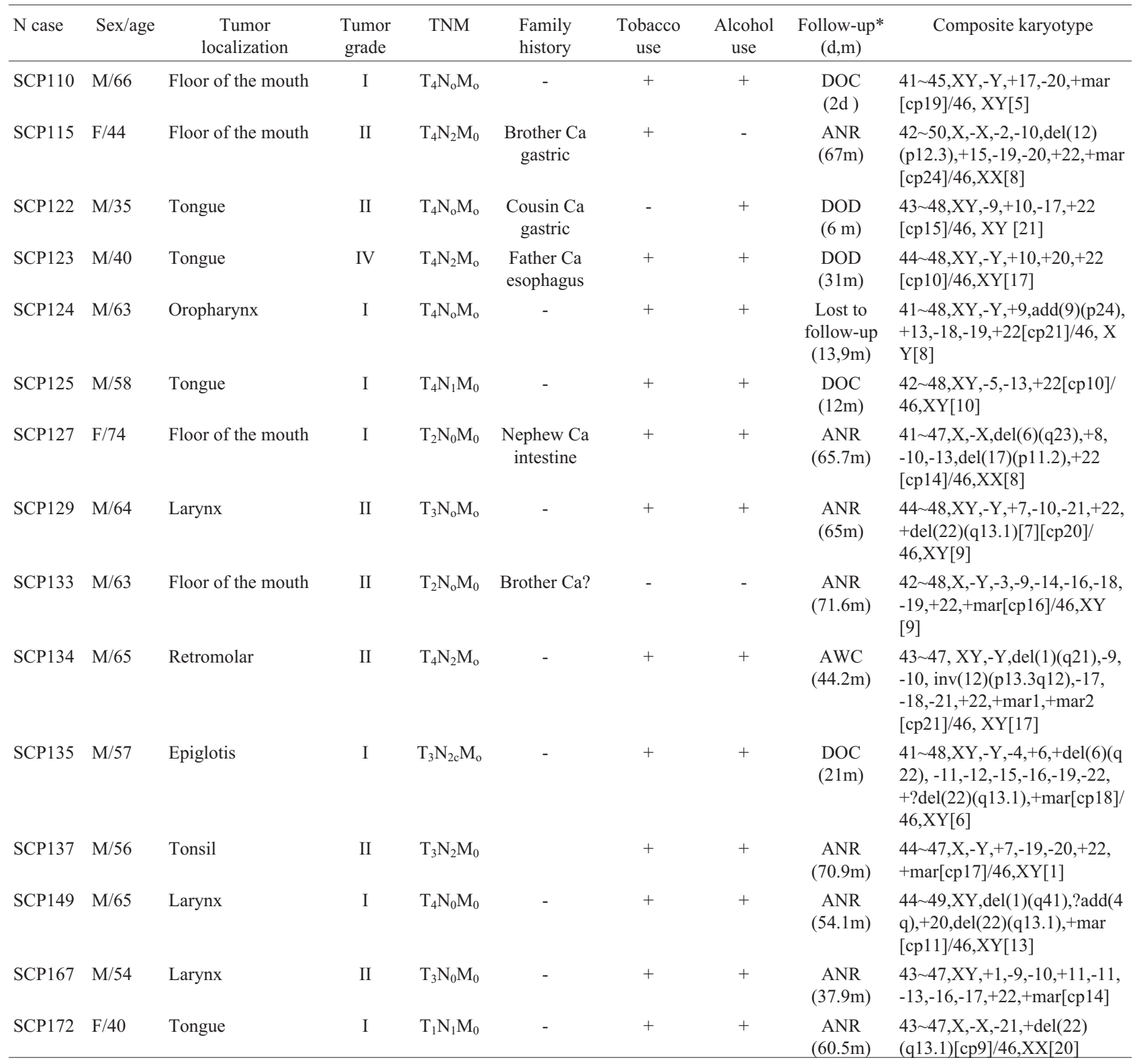

*Since surgery until August 2002.

Abbreviations: Ca: carcinoma; (-): negative history; (+): positive history; d: days; m: months; DOC: died for other causes; DOD: died of disease; ANR: alive with non recurrence; AWC: alive with cancer. Survival time since the surgery is in parenthesis. 
tion and cytogenetic analysis were carried out by standard techniques on primary cultures, as previously described (Rogatto et al., 1993). The tumor fragments were dissociated with $0.4 \%$ type IV collagenase (Sigma), and the cells were grown in Ham's F-10 medium (Sigma) supplemented with $10 \%$ fetal calf serum. Cultures with an adequate number of mitotic cells were harvested with $0.1 \%$ trypsin and $0.2 \%$ EDTA, treated with a hypotonic solution $(\mathrm{KCl}$ $0.075 \mathrm{M})$, and then fixed with methanol: glacial acetic acid (3:1). Metaphase chromosomes were GTG-banded (Scheres, 1972). The karyotype description and the requirements for clonality were based on ISCN (1995). A further requirement for clonality was that the changes had to be found in at least two culture flasks.

FISH was performed as described previously (Rogatto et al., 1999; Dracopolli, 2000). In brief, the slides were treated with RNase $1 \mathrm{x}$ for $1 \mathrm{~h}$ at $37^{\circ} \mathrm{C}$. After rinsing in $2 \mathrm{xSSC}$ solution, the preparations were dehydrated in ethanol washes $(70 \%, 85 \%$, and $100 \%)$, air-dried, and then denatured in $70 \%$ formamide $/ 2 \mathrm{xSSC}$ at $75^{\circ} \mathrm{C}$ for $90 \mathrm{~s}$ to 120 $\mathrm{s}$. The slides were dehydrated again going through a chilled ethanol series.

FISH was done with commercially available digoxigenin-labelled chromosome 17 centromere probe (D17Z1) and chromosome paintings (Coatasome 5 and Coatasome 16) from Oncor. Hybridization was done overnight at $37{ }^{\circ} \mathrm{C}$, after which the slides were rinsed in $50 \%$ formamide/2xSSC at $45{ }^{\circ} \mathrm{C}$ and then in $2 \mathrm{xSSC}$ at $37{ }^{\circ} \mathrm{C}$. The probes were detected with anti-digoxigenin-rhodamine, and chromosomes were counterstained with DAPI. On average, 100 interphase cells and 16 metaphase cells were analyzed from each sample. Normal controls were phytohemagglutinin-stimulated normal male lymphoblasts. The guidelines followed for FISH analysis were those described by Hopman et al. (1992). A case was considered to carry a numerical chromosome abnormality when the percentage of cells displaying an abnormal number of hybridization signals was higher than the mean value plus two standard deviations obtained for the same chromosome in the normal control. The results were verified independently by a second observer.

\section{Results}

The karyotypes of the 15 tumors based on GTGbanding analysis are shown in Table 1. Chromosome banding analysis showed complex karyotypes, with multiple numerical and structural alterations in almost all cases. Normal cells were detected at a low frequency, except in case SCP167. The most frequent numerical changes involved gain of chromosome 22 (11 cases) and loss of chromosomes Y (eight cases), 19 (five cases), 10 (five cases), and 17 (three cases). The most frequent structural alteration was $\operatorname{del}(22)(q 13.1)$.

By G-banding analysis, total or partial loss of chromosome 17 was found to be clonal in four out of the 15

cases (SCP122, SCP127, SCP134, and SCP167). In addition, the loss of chromosome 17 was non-clonal in four cases (cases SCP133, SCP110, SCP137, and SCP149). Chromosome 17 gain was clonal in one case (SCP110) and non-clonal in three others (SCP127, SCP129, and SCP149). Interphase FISH analysis revealed monosomy 17 in all cases, at a frequency ranging from $50 \%$ to $78 \%$ (Figure 1, Table 2).

Five cases (SCP122, SCP129, SCP134, SCP135, SCP149) were analyzed using the painting probe Coatasome 5. In three of these cases a marker chromosome was present that could not be identified by the banding pattern (SCP134, SCP135, and SCP149). The selection of the other two cases was based on the quality of the preparations. On average, 13 metaphases were analyzed from each tumor. The probe did not hybridize to the markers, but in
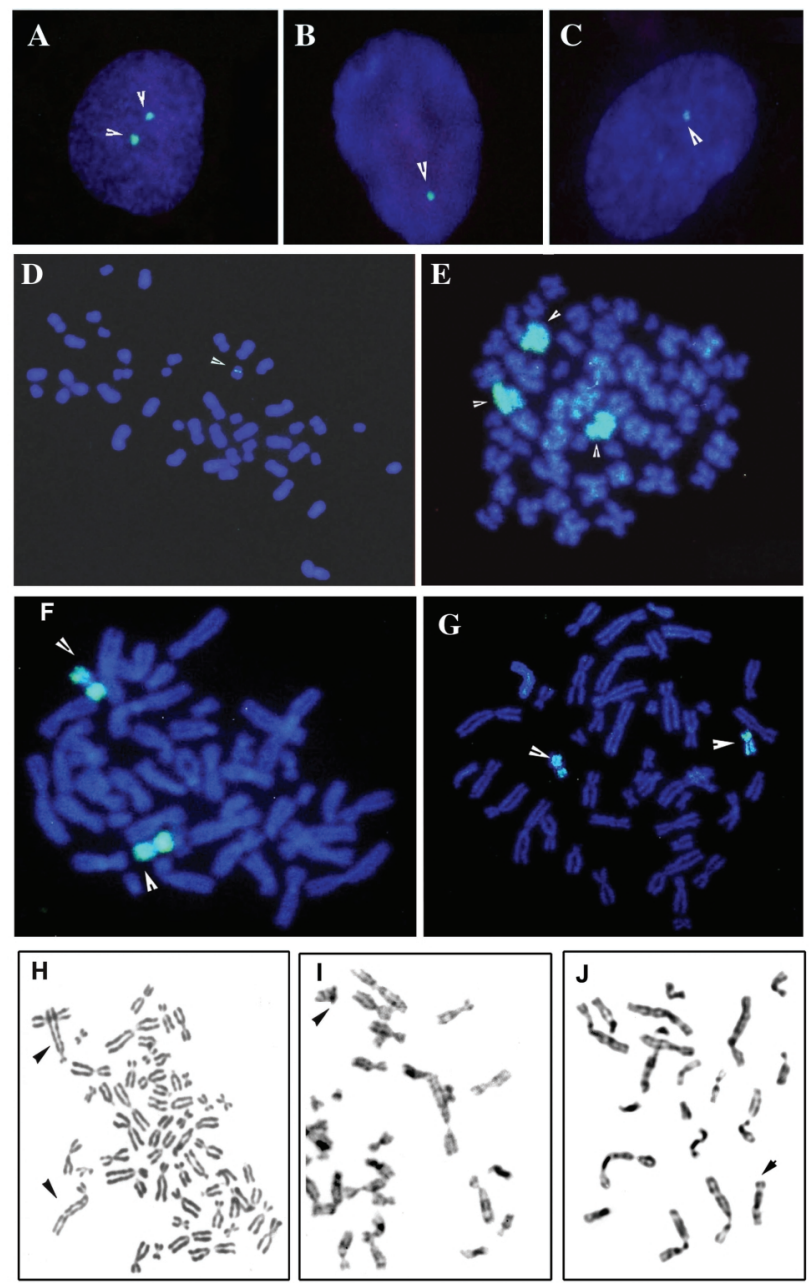

Figure 1 - FISH on metaphase chromosomes and interphase nuclei: (A D) D17Z1 probe for chromosome 17 centromere hybridized to a control sample (A) and to tumor cases SCP122 (B), SCP135 (C), and SCP 134 (D), revealing monosomy 17 (only one hybridization signal) in all three tumors. (E) Trisomy of chromosome 5 observed in 1/13 metaphases after hybridization with chromosome 5 painting probe in case SCP122. (F - G) Disomy of chromosome 16 observed in cases SCP134 and SCP167. (H - J) The marker chromosomes (arrowheads) detected by G-band analysis in cases SCP134, SCP167, and SCP149. 
Table 2- Summary of the chromosomal aberrations detected by FISH.

\begin{tabular}{|c|c|c|c|c|c|}
\hline \multicolumn{6}{|c|}{ Chromosome 17 (D17Z1) } \\
\hline \multirow[t]{2}{*}{ Case } & \multicolumn{4}{|c|}{ Number of signals } & \multirow{2}{*}{$\begin{array}{l}\text { Total number of } \\
\text { interphase cells }\end{array}$} \\
\hline & 1 & 2 & 3 & 4 & \\
\hline SCP 110 & 59 & 37 & 3 & 1 & 100 \\
\hline SCP 115 & 54 & 48 & 2 & 1 & 105 \\
\hline SCP 122 & 64 & 36 & - & - & 100 \\
\hline SCP 123 & 65 & 19 & - & - & 84 \\
\hline SCP 124 & 50 & 47 & 3 & - & 100 \\
\hline SCP 125 & 78 & 20 & 2 & - & 100 \\
\hline SCP 127 & 53 & 38 & 9 & - & 100 \\
\hline SCP 129 & 65 & 33 & 2 & - & 100 \\
\hline SCP 133 & 62 & 38 & - & - & 100 \\
\hline SCP 134 & 61 & 38 & 1 & - & 100 \\
\hline SCP 135 & 50 & 48 & 2 & - & 100 \\
\hline SCP 137 & 69 & 29 & 2 & - & 100 \\
\hline SCP 149 & 55 & 40 & 5 & - & 100 \\
\hline SCP 167 & 59 & 38 & 3 & - & 100 \\
\hline SCP172 & 72 & 28 & - & - & 100 \\
\hline Control & 10 & 73 & 16 & 1 & 100 \\
\hline \multicolumn{6}{|c|}{ Chromosome 5 (Coatasome 5) } \\
\hline \multirow[t]{2}{*}{ Case } & \multicolumn{4}{|c|}{ Number of signals } & \multirow{2}{*}{$\begin{array}{l}\text { Total number of } \\
\text { metaphase cells }\end{array}$} \\
\hline & 1 & 2 & 3 & 4 & \\
\hline SCP 122 & 3 & 9 & 1 & - & 13 \\
\hline SCP 129 & 8 & 8 & - & - & 16 \\
\hline SCP 134 & 4 & 11 & - & - & 15 \\
\hline SCP 135 & 1 & 14 & - & - & 15 \\
\hline SCP 149 & 1 & 5 & - & - & 6 \\
\hline \multicolumn{6}{|c|}{ Chromosome 16 (Coatasome 16) } \\
\hline \multirow[t]{2}{*}{ Case } & \multicolumn{4}{|c|}{ Number of signals } & \multirow{2}{*}{$\begin{array}{l}\text { Total number of } \\
\text { metaphase cells }\end{array}$} \\
\hline & 1 & 2 & 3 & 4 & \\
\hline SCP 122 & - & 7 & - & - & 7 \\
\hline SCP 134 & - & 18 & - & - & 18 \\
\hline SCP 167 & - & 34 & - & - & 34 \\
\hline
\end{tabular}

four cases (SCP122, SCP129, SCP134, and SCP149), loss of chromosome 5 was detected in more than $16 \%$ of the metaphases (Figure 1, Table 2).

A painting probe for chromosome 16 was used in three cases (SCP122, SCP134, and SCP167), two of them showing marker chromosomes (SCP122 and SCP134). In all cases the metaphases analyzed had disomy 16 , and the marker did not show any hybridization signal (Figure 1, Table 2).

\section{Discussion}

Cytogenetic analysis of head and neck tumors has revealed extensive genetic heterogeneity and karyotype complexity (Oh and Mao, 1997; Scully and Field, 1997; Scully et al., 2000; Gollin, 2001). The pattern of chromosome alterations observed in our study by G-banding, as well as the identification of the most frequently aberrant chromosomes, was consistent with other reports on the cytogenetics of head and neck carcinomas (Mertens et al., 1997; Gollin, 2001; Jin et al., 2002; Mitelman et al., 2003).

In our study, FISH analysis showed a high frequency of monosomy 17 in all cases of head and neck carcinomas, regardless of the anatomical subsites (oral, laryngeal, and oropharyngeal tumors). In contrast, monosomy 17 was detected by G-banding in only three cases $(20 \%)$. In her meta-analysis of a series of classical cytogenetic studies in HNSCC, Gollin (2001) estimated that $26 \%$ of these tumors had loss of chromosome 17. The discrepancy between the two methods (FISH and G-banding) in detecting this aneuploidy may result from the smaller number of metaphase analyzed as well as the criteria adopted for sorting these metaphases. 
Soder et al. (1995), using a centromere probe for chromosome 17 in 51 HNSCC samples, demonstrated the gain and loss of chromosome 17 in six and thirteen cases, respectively. In a more recent study, Ai et al. (2001) used FISH in the study of paraffin-embedded tissue sections from 16 patients with HNSCC, including sites with normal mucosa, dysplasia, and invasive tumors. Loss of chromosome 17 was detected in a large fraction of cells in dysplasias, but its gain was prevalent in invasive carcinomas.

Comparative genomic hybridization $(\mathrm{CGH})$ studies in HNSCC have identified non-random chromosomal gains and losses affecting chromosome 17, most often 17q gains and 17p losses (Brzoska et al., 1995; Speicher et al., 1995, Bockmühl et al., 1996; 2000; 2002; Hashimoto et al., 2001; Redon et al., 2001; Huang et al., 2002; Squire et al., 2002). The concomitant gain and loss of chromosome 17 segments suggest that cooperation exists between genes mapped at $17 \mathrm{p}$ and $17 \mathrm{q}$, mediated by deletions of $17 \mathrm{p}$ and amplifications of segments of 17q. This phenomenon has been described in cell lung carcinoma (Varella-Garcia et al., 1998).

Loss of heterozygosity, deletions and other rearrangements involving chromosome 17, particularly the TP53 gene, are the most common mutations investigated in cancer. The TP53 gene is involved in many functions maintaining cellular integrity after DNA damage, and TP53 mutations have been demonstrated in up to two-thirds of HNSCC, ranging from $12 \%$ to $100 \%$ in different series (Chang et al., 1992; Hainaut et al., 1998; Nagai et al., 1998; Kropveld et al., 1999; review in Scully et al., 2000, Beder et al., 2003). TP53 mutations have been correlated with alcohol and tobacco exposure, and they appear to be associated with a short recurrence time (Shin et al., 1996). In addition, Blons et al. (1999) showed that loss of heterozygozity at $17 \mathrm{p}$ was predictive of low response to chemoterapy, indicating that TP53 alterations could play a role in chemoterapy resistance in HNSCC.

Reports of one group showed an increased copy number of the HER2 gene (17q11) in oral cavity HNSCC (Brandt et al., 1995; Werkmeister et al., 1996; 2000). In addition, several studies have demonstrated increased HER2/ERBB2 oncoprotein levels (Werkmeister et al., 1996; Ibrahim et al., 1999; Xia et al., 1999).

In our study, loss of chromosome 17 was not associated with clinical and histopathological parameters such as TNM staging, grade, familial or personal history of cancer, or tobacco and alcohol usage. Among the cases with the highest frequencies of loss, one (SCP125) died from other causes 12 months after surgery, while the other (SCP172) was alive without recurrence 60 months after surgery. HNSCC is thought to result from a multistep process (Nawroz et al., 1994; Califano et al., 1996), and a specific genetic event is expected to contribute only partially to the cancer phenotype (Hanahan and Weinberg, 2000).

We studied chromosome 5 by FISH in five cases, three of which showed markers that could not be identified by G-banding. The reasons for selecting this particular chromosome were that $\mathrm{i}(5 \mathrm{p})$ is one of the most frequent structural rearrangements in HNSCC $(10 \%$ of the cytogenetically abnormal cases), and chromosome 5 has been repeatedly reported to participate in whole-arm rearrangements with other chromosomes (El-Naggar et al.,1994; Ransom et al., 1998; Martins et al.,1999, Squire et al., 2002; Mitelman et al., 2003). Our FISH results showed significant loss of chromosome 5 in four cases, in which monosomy of chromosome 5 had been found to be nonclonal by G-banding analysis. The markers present in three of these cases could not be identified by the probe used.

Abnormalities of chromosome 16 were not detected in the three tumors studied after hybridization with chromosome 16 painting probe, two of them carrying marker chromosomes. A minority of HNSCC cases show loss of heterozygosity on 16p or 16q (Ah-See et al., 1994; Nawroz et al., 1994; Field, 1995), and some translocations have been found involving 16q22 (Owens et al., 1992). Loss of chromosome 16 has been detected by comparative genomic hybridization in a small number of HNSCC cases (Brzoska et al., 1995; Bockmühl et al., 1996; Komiyama et al., 1997; Wolff et al., 1998).

FISH strategies have enhanced the ability to detect subtle genomic changes and to diagnose complex karyotypes with marker chromosomes. However, standard FISH analysis requires the knowledge of the segments involved in the chromosome aberration, and, without a hint from the G-banding pattern, FISH analysis can be extremely laborious or even not feasible. The markers detected in our study could not be identified by G-banding, because they were either too small or showed poor band resolution. Recently, a new molecular cytogenetic technology, generically termed multi-fluorochrome FISH or M-FISH, has provided the means to directly examine the entire genome in one FISH experiment, thus allowing the elucidation of chromosomal rearrangements, including complex structural alterations that result in marker chromosomes (Bayani and Squire, 2001).

Multiple tumor-associated chromosome alterations occur in HNSCC. Our FISH results as well as other previously reported findings suggest that losses of genes mapped at chromosome 17 play a role in the pathogenesis of HNSCC.

\section{Acknowledgments}

This study was supported by FAPESP and CNPq, Brazil. 


\section{References}

Ah-See KW, Cooke TG, Pickford IR, Soutar D and Balmain A (1994) Allelo-type of squamous carcinoma of the head and neck using microsatellite. Cancer Res 54:1617-1621.

Ai H, Barrera JE, Meyers AD, Shroyer KR and Varella-Garcia M (2001) Chromosomal aneuploidy precedes morphological changes and supports multifocality in head and neck lesions. Laryngoscope 111:1853-1858.

AJCC, American Joint Committee on Cancer: Manual for Staging of Cancer (1998) 4th edition. JB Lippincott, Philadelphia.

Bayani J and Squire JA (2001) Advances in the detection of chromosomal aberrations using spectral kayotyping. Clin Genet 59:656-73.

Beder LB, Gunduz M, Ouchida M, Fukushima K, Gunduz E, Ito S, Sakai A, Nagai N, Nishizaki K and Shimizu K (2003) Genome-wide analysis on loss of heterozygosity in head and neck squamous cell carcinomas. Lab Invest 83:99-105.

Blons H, Cabelguenne A, Carnot F, Laccourreye O, de Waziers I, Hamelin R, Brasnu D, Beaune P and Laurent-Puig P (1999) Microsatellite analysis and response to chemotherapy in head and neck squamous cell carcinoma. Int $\mathrm{J}$ Cancer 84:410-415.

Bockmühl U, Schwendel A, Dietel M and Petersen I (1996) Distinct patterns of chromosomal alterations in high- and low-grade head and neck squamous cell carcinomas. Cancer Res 56:5325-5329.

Bockmühl U, Wolf G, Schmidt S, Schwendel A, Jahnke V, Dietel $\mathrm{M}$ and Petersen I (1998) Genomic alterations associated with malignancy in head and neck cancer. Head Neck 20:145-151.

Bockmühl U, Schulüns K, Küchler I, Petersen S and Petersen I (2000) Genetic imbalances with impact on survival in head and neck cancer patients. Am J Pathol 157: 369-375.

Bockmühl U, Schulüns K, Schimdt S, Matthias S and Petersen I (2002) Chromosomal alterations during metastasis formation of head and neck squamous cell carcinoma. Genes Chromosomes Cancer 33:29-35.

Brandt B, Vogt U, Schlotter CM, Jackisch C, Werkmeister R, Thomas M, von Eiff M, Bosse U, Assmann G and Zanker KS (1995) Prognostic relevance of aberrations in the erbB oncogenes from breast, ovarian, oral and lung cancers: double-differential polymerase chain reaction (ddPCR) for clinical diagnosis. Gene 159:35-42.

Brzoska PM, Levin NA, Fu KK, Kaplan MJ, Singer MI, Gray JW and Christman MF (1995) Frequent novel DNA copy number increase in squamous cell head and neck tumors. Cancer Res 55:3055-3059.

Califano J, van der Riet P, Westra W, Nawroz H, Clayman G, Piantadosi S, Corio R, Lee D, Greenberg B, Koch W and Sidransky D (1996) Genetic progression model for head and neck cancer: implications for field cancerization. Cancer Res 56:2488-2492.

Califano J, Westra WH, Meininger G, Corio R, Koch WM and Sidransky D (2000) Genetic progression and clonal relationship of recurrent premalignant head and neck lesions. Clin Cancer Res 6:347-352.

Chang Y, Lin Y, Tsai C, Shu C, Tsai M, Choo K and Liu ST (1992) Detection of mutations in p53 gene in human head and neck carcinomas by single strand conformation polymorphism analysis. Cancer Lett 67:167-174.

Decker J and Goldstein JC (1982) Risk factors in head and neck cancers. N Engl J Med 306:1151-1155.

Dracopoli NC (2000) Current Protocols in Human Genetics. John Wiley \& Sons, Inc. (CD Version), New York .

El-Naggar AK, Lovell M, Killary A and Batsakis JG (1994) Trisomy 5 as the sole chromosomal abnormality in a primary mucoepidermoid carcinoma of the minor salivary gland. Cancer Genet Cytogenet 76:96-99.

Field JK (1995) The role of oncogenes and tumour-suppressor genes in the aetiology of oral, head and neck squamous cell carcinoma. J R Soc Med 88:35P-39P.

Foulkes WD, Brunet J-S, Kowalski LP, Narod AS and Franco EL (1995) Family history of cancer is a risk factor for squamous cell carcinoma of the head and neck in Brazil: a case-control study. Int J Cancer 63:769-773.

Gollin SM (2001) Chromosomal alterations in squamous cell carcinomas of the head and neck: window to the biology of disease. Head Neck 23:238-253.

Hainaut P, Hernandez T, Robinson A, Rodriguez-Tome P, Flores T, Hollstain M, Harris CC and Montesano R (1998) IARC database of TP53 gene mutation in human tumors and cell lines: updated compilation, revised formats and new visualization tolls. Nucleic Acid Res 26:205-213.

Hanahan D and Weinberg RA (2000) The hallmarks of cancer. Cell 100:57-70.

Hashimoto Y, Oga A, Kawauchi S, Furuya T, Shimizu N, Nakano T, Imate Y, Yamashita H and Sasaki K. (2001) Amplification of 3 q26 approximately qter correlates with tumor progression in head and neck squamous cell carcinomas. Cancer Genet Cytogenet 129:52-56.

Hopman AHN, Ramaekers FCS and Vooijs GP (1992) Interphase cytogenetics of solid tumours. In: Polak JN and McGee JOJ (eds). In situ Hybridization: Principles and Practice. Oxford Science Press. VIII, pp 165-186.

Huang Q, Yu GP, McCormick SA, Mo J, Datta B, Mahimkar M, Lazarus P and Schaffer SP (2002) Genetic differences detected by comparative genomic hybridization in head and neck squamous cell carcinomas from different tumor sites: construction of oncogenetic trees for tumor progression. Genes Chromosomes Cancer 34:224-233.

Ibrahim SO, Lillehaug JR, Johannssen AC, Liavaag PG, Nilsen R and Vasstrand EN (1999) Expression of biomarkers (p53, transforming growth factor alpha, epidermal growth factor receptor, c-erbB-2/neu and the proliferative cell nuclear antigen) in oropharyngeal squamous cell carcinomas. Oral Oncol 35:302-313.

ISCN (1995) An International System for Human Cytogenetic Nomenclature, Mitelman F. (ed.), Skarger, Basel 1995.

Jin Y, Higashi K, Mandahk N, Heim S, Wennerberg J, Biörklund A, Dictor M and Mitelman F (1990) Frequent rearrangement of chromosomal bands $1 \mathrm{p} 22$ and $11 \mathrm{q} 13$ in squamous cell carcinoma of the head and neck. Genes Chromosomes Cancer 2:198-204.

Jin Y, Mertens F, Mandahl N, Heim S, Olegard C, Wennerberg J, Biörklund A and Mitelman F (1993) Chromosome abnormalities in eighty-three head and neck squamous cell carcinomas: Influence of culture conditions on karyotypic pattern. Cancer Res 53:2140-2146. 
Jin Y, Mertens F, Jin C, Akervall J, Wennerberg J, Gorunova L, Mandahl N, Heim S and Mitelman F (1995) Nonrandom chromosome abnormalities in short-term cultured primary squamous cell carcinomas of the head and neck. Cancer Res 55:3204-3210.

Jin C, Jin Y-S, Wennerberg J, Akervall J, Grenthe B, Mandahl N, Heim S, Mitelman F and Mertens F. (1997) Clonal chromosome aberrations accumulate with age in upper aerodigestive tract mucosa. Mutat Res 374:63-72.

Jin Y, Hoglund M, Jin C, Martins C, Wennerberg J, Akervall J, Mandahl N, Mitelman F and Mertens F (1998) FISH characterization of head and neck carcinomas reveals that amplification of band $11 \mathrm{q} 13$ is associated with deletion of distal 11q. Genes Chromosomes Cancer 22:312-320.

Jin C, Jin Y-S, Wennerberg J, Akervall J, Dictor M and Mertens F (2002) Karyotypic heterogeneity and clonal evolution in squamous cell carcinomas of the head and neck. Cancer Genet Cytogenet 132:85-96.

Komiyama T, Matsumura K and Tsuchida N (1997) Comparison of DNA copy numbers in original oral squamous cell carcinomas and corresponding cell lines by comparative genomic hybridization. Jpn J Cancer Res 88:476-483.

Kropveld A, Rozemuller E, Leppers F, Scheidel K, de Weger R, Koole R, Hordijk GJ, Slootweg PJ and Tilanus MG (1999) Sequencing analysis of RNA and DNA of exons 1 through 11 shows p53 gene alterations to be present in almost 100\% of head and neck squamous cell cancers. Lab Invest 79:347-353.

Martins C, Jin Y, Jin C, Wennerberg J, Höglund M and Mertens F (1999) Fluorescent in situ hybridization (FISH) characterization of pericentromeric breakpoints on chromosome 5 in head and neck squamous cell carcinomas. Eur J Cancer 35:498-501.

Mertens F, Johansson B, Hoglund M and Mittelman F (1997) Chromosomal imbalance maps of malignant solid tumors: a cytogenetic survey of 3185 neoplasms. Cancer Res 57:2765-2780.

Mitelman F, Johansson B and Mertens F (2003) Mitelman Database of Chromosome Aberration in Cancer. Mitelman F, Johansson B, Mertens F (eds). http://cgap.nci.nih.gov/Chromosomes/Mitelman.

Nagai MA, Miracca EC, Yamamoto L, Moura RP, Simpson AJ, Kowalski LP and Brentani RR. (1998) TP53 genetic alterations in head and neck carcinomas from Brazil. Int. J. Cancer 76:13-18.

Nawroz H, van der Riet P, Hruban RH, Koch W, Ruppert JM and Sidransky D (1994) Allelotype of head and neck squamous cell carcinoma. Cancer Res 54:1152-1155.

Nowell PC (1976) The clonal evolution of tumor cell populations. Science 194:23-28.

Oh Y and Mao L (1997) Biomarkers in head and neck carcinoma. Curr Opin Oncol 9:247-256.

Owens W, Field JK, Howard PJ and Stell PM (1992) Multiple cytogenetic aberrations in squamous cell carcinomas of the head and neck. Oral Oncol Eur J Cancer 28B:17-21.

Ransom DT, Barnett TC, Bot J, de Boer B, Metcalf C, Davidson JA and Turbett GR (1998) Loss of heterozygosity on chromosome 2q: possibly a poor prognostic factor in head and neck cancer. Head Neck 20:404-410.
Rao PH, Sreekantalah C, Schantz SP and Chaganti RSK (1994) Cytogenetic analysis of 11 squamous cell carcinomas of the head and neck. Cancer Genet Cytogenet 77:60-64.

Redon R, Muller D, Caulee K, Wanherdrick K, Abecassis J and du Manoir S (2001) A simple specific pattern of chromosomal aberrations at early stages of head and neck squamous cell carcinomas: PIK3CA but not p63 gene as a likely target of 3q26-qter gains. Cancer Res 61:4122-4129.

Reid BC, Winn DM, Morse DE and Pendrys DG (2000) Head and neck in situ carcinoma: incidence, trends and survival. Oral Oncol 36:414-420.

Rogatto SR, Casartelli C, Rainho CA and Barbieri-Neto J (1993) Chromosomes in the genesis and progression of ependymomas. Cancer Genet Cytogenet 69:146-152.

Rogatto SR, Rainho CA, Zhang ZM, Figueiredo F, Barbieri-Neto J, Georgetto SM and Squire JA (1999) Hemangioendothelioma of bone in a patient with a constitutional supernumerary marker. Cancer Genet Cytogenet 110:23-27.

Scheres Vac MJC (1972) Identification of two Robertsonian translocations with a Giemsa banding technique. Hum Genet 15:253-256.

Scully C and Field JK (1997) Genetic aberrations in squamous cell carcinoma of the head and neck (SCCHN), with reference to oral carcinoma (Review). Int J Oncol 10:5-21.

Scully C, Field JK and Tanzawa H (2000) Genetic aberrations in oral or head and neck squamous cell carcinoma 2: chromosomal aberrations. Oral Oncol 36:311-327.

Shin DM, Lee JS, Lippman SM, Lee JJ, Tu ZN, Choi G, Heyne K, Shin HJ, Ro JY, Goepfert H, Hong WK and Hittelman WN. (1996) p53 expressions: predicting recurrence and second primary tumours in head and neck squamous cell carcinoma. J Natl Cancer Inst 88:519-529.

Soder AI, Hopman AHN, Ramaekers FCS, Conradt C and Bosch FX (1995) Distinct nonradom patterns of chromosomal aberrations in the progression of squamous cell carcinomas of the head and neck. Cancer Res 55:5030-5037.

Speicher MR, Howe C, Crotty P, du Manoir S, Costa J and Ward DC (1995) Comparative genomic hybridization detects novel deletions and amplifications in head and neck squamous cell carcinomas. Cancer Res 55:1010-1013.

Squire JA, Bayani J, Luk C, Unwin L, Tokunaga J, MacMillan C, Irish J, Brown D, Gullane P and Kamel-Reid S (2002) Molecular cytogenetic analysis of head and neck squamous cell carcinoma: by comparative genomic hybridization, spectral karyotyping, and expression array analysis. Head Neck 24:874-887.

van Dyke DL, Worsham MJ, Benninger MS, Krause CJ, Baker SR, Wolf GT, Drumheller T, Tilley BC and Carey TE. (1994) Recurrent cytogenetic abnormalities in squamous cell carcinomas of the head and neck region. Genes Chromosomes Cancer 9:192-206.

Varella-Garcia M, Gemmill RM, Rabenhorst SH, Lotto A, Drabkin HA, Archer PA and Franklin WA. (1998) Chromosomal duplication accompanies allelic loss in non-small cell lung carcinoma. Cancer Res 58:4701-4707.

Werkmeister R, Brandt B and Joos U (1996) The erbB oncogene as prognostic markers in oral squamous cell carcinomas. Am J Surg 172:681-683. 
Werkmeister R, Brandt B and Joos U (2000) Clinical relevance of erbB-1 and -2 oncogenes in oral carcinomas. Oral Oncol 36:100-105.

Wolff E, Girod S, Liehr T, Vorderwulbecke U, Ries J, Steininger $\mathrm{H}$ and Gebhart E. (1998) Oral squamous cell carcinomas are characterized by a rather uniform pattern of genomic imbalances detected by comparative genomic hybridization. Oral Oncol 34:186-190.
World Health Organization (1990) International Classification of Diseases for Oncology, 2nd edition. World Health Organization, Geneva.

Xia W, Lau YK, Zhang HZ, Xiao FY, Johnston DA, Liu AR, Li L, Katz RL and Hung MC (1999) Combination of EGFR, Her-2/neu, and HER-3 is a stronger predictor for the outcome of oral squamous cell carcinoma than any individual family members. Clin Cancer Res 5:4164-4174. 